\title{
OPINIONS ABOUT COMMUNITY PHARMACY-BASED HEALTH SCREENINGS FROM PATIENTS' LIVING IN RIYADH (SAUDI ARABIA), POZNAN (POLAND) AND CHICAGO (UNITED STATES OF AMERICA)
}

\author{
MAGDALENA WASZYK-NOWACZYK ${ }^{1}{ }^{*}$, WERONIKA GUZENDA ${ }^{1}$, SAIF ALKATHIRI ${ }^{2}$, \\ ANNA RATKA ${ }^{3}$
}

${ }^{I}$ Department of Pharmaceutical Technology, Pharmacy Practice Division, Poznan University of Medical Sciences, 6 Grunwaldzka Street, 60-780 Poznan, Poland

${ }^{2}$ Prince Sultan Military Medical City, Makkah road. Al Sulimaniyah, Riyadh, Saudi Arabia

${ }^{3}$ Wegmans School of Pharmacy, St. John Fisher College, 3690 East Avenue, Rochester, NY 14618, United States of America

*corresponding author: mwaszyk@ump.edu.pl

\begin{abstract}
The aim of the study was to collect, evaluate and compare opinions about health screening services in community pharmacies from participants located in Riyadh, Poznan, and Chicago. The cross-sectional study based on a questionnaire was carried out between March 2016 and March 2017. Total of 557 respondents participated in this study, including 102 from Riyadh, 265 from Poznan, and 190 from Chicago. The study showed that patients were very interested in participating in community pharmacy-based health screening services. The vast majority of respondents in Riyadh, Poznan, and Chicago (67.6\%, 66.8\%, and $58.0 \%$, respectively), was willing to participate in such health screenings ( $\mathrm{p}<0.05$ ). More than half of participants from Riyadh could pay about 10-19 PLN/SAR (2.4 - 4.9 USD). Most Poznanians declared that they would be willing to pay about 20-29 PLN/SAR (5.0 - 7.4 USD) for such a service. Respondents in Chicago were willing to pay above 100 PLN (25.3 USD). The vast majority of Saudi participants indicated that a community pharmacy should finance cost for screening (78.6\%), Polish respondents chose the government as the source of funding (84.9\%). Whereas, the American participants chose the government and the insurance company ( $44.6 \%$ and $41.0 \%$, respectively). Among all respondents, more than half expressed opinion for the government as the funding source for community pharmacy-based health screenings $(58.1 \%$; $\mathrm{p}<0.05)$. For decades, in many countries, community pharmacies and devoted pharmacists offer to patients' health care services that help to identify and alleviate health problems, provide expert counselling and advice based on patient-specific health conditions, and often collaborate with a physician or other members of the healthcare. Implementing a new service to a community pharmacy should contribute to improved outcomes in patient's health and quality of life.
\end{abstract}

\section{Rezumat}

Scopul studiului a fost de a colecta, evalua și compara opiniile despre serviciile de screening pentru sănătate în farmaciile comunitare de la participanții aflați în Riyadh, Poznan şi Chicago. Studiul transversal bazat pe un chestionar a fost realizat în perioada martie 2016 - martie 2017. În total au participat 557 respondenți, inclusiv 102 din Riyadh, 265 din Poznan și 190 din Chicago. Studiul a arătat că pacienții erau foarte interesați să participe la serviciile de screening în farmacii comunitare. Marea majoritate a respondenților din Riyadh, Poznan și Chicago $(67,6 \%, 66,8 \%$ și, respectiv, 58,0\%) au fost dispuși să participe la astfel de monitorizări $(\mathrm{p}<0,05)$. Mai mult de jumătate dintre participanții din Riyadh ar putea plăti aproximativ 10 - 19 PLN/SAR (2,4 - 4,9 USD). Majoritatea locuitorilor din Poznan au declarat că ar plăti aproximativ 20 - 29 PLN/SAR (5,0 - 7,4 USD) pentru un astfel de serviciu. Respondenții din Chicago au fost dispuși să plătească peste 100 PLN (25,3 USD). Marea majoritate a participanților saudiți au precizat că o farmacie comunitară ar trebui să finanțeze costurile pentru screening $(78,6 \%)$ iar respondenții polonezi vor guvernul ca sursă de finanțare $(84,9 \%)$. Participanții americani au ales guvernul și compania de asigurări (44,6\%, respectiv 41,0\%). Dintre toți respondenții, mai mult de jumătate doresc ca guvernul să fie finanțatorul acestor tipuri de programe desfăşurate în farmacii comunitare $(58,1 \%$; $<<0,05)$.

Keywords: community pharmacy, health screening services, pharmaceutical care, pharmacist

\section{Introduction}

Community pharmacies have been providing variety of health services to patients for many years. The role of most pharmacist includes dispensing of medicines, counselling and expert advice, and participation in disease prevention programs and promotion of health [5]. In addition, community pharmacies are easily-accessible healthcare sites where people seek professional assistance and ask for advice about treatment of minor acute ailments as well as chronic diseases. Therefore, community pharmacies are adequately positioned to provide 
professional quality health screening programs that can assist physicians with early diagnosis or identification of risk factors $[2,11]$.

The pharmacist is usually the first health care professional contacted by patients; therefore, it is extremely important to involve pharmacists in the early detection of prevalent chronic diseases such as hypertension, diabetes or metabolic syndrome [14]. Health screenings are invaluable in detection of diseases and potential risk factors. Early identification of health problems through screenings tests and may be carried out routinely as a preventive measure or when there is reason to suspect that a health problem exists. If health problems are detected during screening, patients are referred immediately to a healthcare professional for additional evaluation and therapy. Studies show that patients are open and willing to participate in health services in community pharmacies [15]. Through greater involvement of pharmacies in patient care, the cost of health care has become less expensive. This outcome is the result not only of legislative measures, but also greater emphasis on better patient outcomes [9].

In this study the objective opinions about health screenings conducted in community pharmacies were collected from patients from Saudi Arabia, Poland, and the USA. The aim was to collect, evaluate, and compare opinions about community pharmacy-based health screening services in Riyadh, Poznan and Chicago.

\section{Materials and Methods}

The authors' questionnaire was carried out from March 2016 to March 2017, as a cross sectional study. This survey questions were constructed to determine the objective opinions about the new health screenings in the community pharmacy. Study participants voluntarily agreed to complete the questionnaire. The survey involved 557 respondents from three countries; 102 from Riyadh (Saudi Arabia), 265 from Poznan (Poland), and 190 from Chicago (USA).

The anonymous questionnaire was developed in English and Polish by the authors of this study who are pharmacists. In cases where the respondent had a problem with English, a bilingual pharmacist translated the survey into Arabic to ensure consistency in the content of the questions. The survey was validated by licensed pharmacists in Riyadh, Poznan, and Chicago. The survey included also a short description of the new services. Participation in this study was anonymous. All collected data were securely stored in the Department of Pharmaceutical Technology, Pharmacy Practice Division at Poznan University of Medical Sciences (Poland). The study was conducted in accordance with the Declaration of Helsinki, and the protocol was approved by the Ethics Committee.

The Statistica PL 12 (StatSoft) package was used to perform the statistical analysis. The correlations between analysed nominal data were performed by Chi-square test of independence. All statistical analyses were performed at $\mathrm{p}<0.05$.

\section{Results and Discussion}

The characteristics of study participants are presented in Table I. The largest number of respondents were at age of 18 to 30 years; $33.3 \%$ among Saudis, $32.4 \%$ among Poles, and 23.2\% among Americans. The age group of 41 to 50 years was mostly represented among Americans (32.4\%). The majority of the responding participants in Riyadh, Poznan and Chicago had graduate education, $62.8 \%, 37.7 \%$ and $37.9 \%$, respectively.

The study showed that patients were very interested in participating in health screening services (Table II). In Riyadh, Poznan and Chicago, the vast majority would be willing to take part in health screenings and counselling, $67.6 \%, 66.8 \%$ and $58.0 \%$, respectively $(\mathrm{p}<0.05)$.

Moreover, respondents provided their opinion about the cost of screening services and potential source of funds to cover these costs (Table III). More than half of Riyadh residents could pay 10-19 PLN/SAR (2.4 - 4.9 USD). Most Poznanians declared that they would be willing to pay 20-29 PLN/SAR (5.0 - 7.4 USD). The Chicago residents were willing to pay above 100 PLN (25.3 USD). The majority of all responders combined was in favour of paying 20 29 PLN/SAR (5.0 - 7.4 USD).

Respondents were asked about their preference for source of funding for health screenings in a community pharmacy. Data presented in Table IV show that the vast majority of Saudis (78.6\%) indicated that a community pharmacy should finance health screenings. The majority $(84.9 \%)$ of Poles expressed opinion that the government should provide funding for screenings. Whereas, the Americans from Chicago indicated that the government and the insurance company (44.6\% and $41.0 \%$, respectively) should cover the cost of health screening. More than half of all respondents $(58.1 \%)$ chose the government as the institution to fund health screenings $(\mathrm{p}<0.05)$. 
Table I

Characteristics of study participants

\begin{tabular}{|c|c|c|c|c|}
\hline & \multicolumn{4}{|c|}{ n (\%) } \\
\hline & Riyadh & Poznan & Chicago & Total \\
\hline Total respondents & $102(100.0)$ & $265(100.0)$ & $190(100.0)$ & $557(100.0)$ \\
\hline Gender & & & & \\
\hline Female & $55(53.9)$ & $167(63.0)$ & $109(57.4)$ & $331(59.4)$ \\
\hline Male & $47(46.1)$ & $98(37.0)$ & $81(42.6)$ & $226(40.6)$ \\
\hline Age [years] & & & & \\
\hline $18-30$ & $34(33.3)$ & $86(32.4)$ & $44(23.2)$ & $164(29.5)$ \\
\hline $31-40$ & $24(23.5)$ & $34(12.8)$ & $36(18.9)$ & $94(16.9)$ \\
\hline $41-50$ & $16(15.7)$ & $60(22.6)$ & $44(23.2)$ & $120(21.5)$ \\
\hline $51-60$ & $18(17.7)$ & $55(20.8)$ & $29(15.3)$ & $102(18.3)$ \\
\hline $61-70$ & $7(6.9)$ & $19(7.2)$ & $28(14.7)$ & $54(9.7)$ \\
\hline$>70$ & $3(2.9)$ & $11(4.2)$ & $9(4.7)$ & $23(4.1)$ \\
\hline Education & & & & \\
\hline Primary & $1(1.0)$ & $4(1.5)$ & $3(1.6)$ & $8(1.4)$ \\
\hline Vocational & $14(13.7)$ & $32(12.1)$ & $17(8.9)$ & $63(11.3)$ \\
\hline High school & $9(8.8)$ & $62(23.4)$ & $58(30.5)$ & $129(23.2)$ \\
\hline College & $14(13.7)$ & $67(25.3)$ & $40(21.1)$ & $121(21.7)$ \\
\hline Graduate & $64(62.8)$ & $100(37.7)$ & $72(37.9)$ & $236(42.4)$ \\
\hline
\end{tabular}

Table II

Interest in participating in health screenings in a community pharmacy

\begin{tabular}{|c|c|c|c|c|c|}
\hline \multirow{2}{*}{ Interest in health screenings } & \multicolumn{4}{|c|}{$\mathbf{n}(\%)$} & \multirow{2}{*}{ p } \\
\cline { 2 - 5 } & Riyadh & Poznan & Chicago & Total & \\
\hline Total respondents & $102(100.0)$ & $265(100.0)$ & $188(100.0)$ & $555(100.0)$ & \\
\hline Yes & $69(67.6)$ & $177(66.8)$ & $109(58.0)$ & $355(64.0)$ \\
\hline No & $1(1.0)$ & $47(17.7)$ & $43(22.9)$ & $91(16.4)$ & \multirow{2}{*}{$\mathrm{p}<0.05^{*}$} \\
\hline I don't know & $32(31.4)$ & $41(15.5)$ & $36(19.1)$ & $109(19.6)$ & \\
\hline
\end{tabular}

* statistically significant results

Table III

Preference for cost of health screenings in a community pharmacy

\begin{tabular}{|c|c|c|c|c|}
\hline The cost for health screenings & \multicolumn{3}{|c|}{ n (\%) } \\
\cline { 2 - 4 } [PLN=SAR /USD] & Riyadh & Poznan & Chicago & Total \\
\cline { 2 - 5 } & $24(100.0)$ & $129(100.0)$ & $75(100.0)$ & $228(100.0)$ \\
\hline $1-9 / 0.3-2.3$ & $2(8.3)$ & $17(13.2)$ & $0(0.0)$ & $19(8.3)$ \\
\hline $10-19 / 2.4-4.9$ & $13(54.2)$ & $22(17.0)$ & $1(1.3)$ & $36(15.8)$ \\
\hline $20-29 / 5.0-7.4$ & $4(16.7)$ & $42(32.6)$ & $2(2.8)$ & $48(21.1)$ \\
\hline $30-39 / 7.5-10.0$ & $3(12.4)$ & $28(21.7)$ & $13(17.3)$ & $44(19.3)$ \\
\hline $40-49 / 10.1-12.5$ & $1(4.2)$ & $4(3.1)$ & $6(8.0)$ & $11(4.8)$ \\
\hline $50-99 / 12.6-25.2$ & $1(4.2)$ & $14(10.9)$ & $22(29.3)$ & $37(16.2)$ \\
\hline$\geq 100 / \geq 25.3$ & $0(0.0)$ & $2(1.5)$ & $31(41.3)$ & $33(14.5)$ \\
\hline
\end{tabular}

Table IV

Preference for source of funding for health screenings in a community pharmacy

\begin{tabular}{|c|c|c|c|c|c|}
\hline \multirow[t]{2}{*}{ Source of funding for health screenings } & \multicolumn{4}{|c|}{ n $(\%)$} & \multirow[b]{2}{*}{$\mathbf{p}$} \\
\hline & Riyadh & Poznan & Chicago & Total & \\
\hline Total respondents & $98(100.0)$ & $265(100.0)$ & $188(100.0)$ & $551(100.0)$ & \multirow{4}{*}{$\mathrm{p}<0.05^{*}$} \\
\hline Insurance company & $10(10.2)$ & $30(11.3)$ & $77(41.0)$ & $117(21.2)$ & \\
\hline Government & $11(11.2)$ & $225(84.9)$ & $84(44.6)$ & $320(58.1)$ & \\
\hline Community pharmacy & $77(78.6)$ & $10(3.8)$ & $27(14.4)$ & $114(20.7)$ & \\
\hline
\end{tabular}

* statistically significant results

Disease prevention and health promotion are very important for society and public health. The high prevalence of chronic diseases is a huge global health care challenge for interdisciplinary teams of health professionals with a pharmacist as a significant member [14]. Regular check-ups and screenings can help with early detection of a health problem and consequently, increases the chance for recovery. Access to adequate health services, screenings, and treatments, help patients to have longer and healthier 
life [21]. It is important to improve preventive health care by implementing new health screening services in a pharmacy and improving cooperation between pharmacists and physicians [19]. In addition, it is crucial to inform patients about additional health care services available in a community pharmacy. In this study, patients were asked about their interest in participating in health screening in a community pharmacy. More than a half of respondents from Riyadh, Poznan and Chicago expressed interest in participating in pharmacy-based screenings. Another study also showed that patients were interested in education about chronic diseases and participation in health screenings [23]. Numerous literature reports confirmed that most patients are eager to receive from a pharmacist professional advice about disease prevention and healthy lifestyle [9, 17, 23]. That's why many community pharmacies around the world have successfully implemented health screenings and confirmed its efficacy and benefits. For example, in the United Kingdom, the Netherlands, Germany, Denmark, Italy, Sweden and France, pharmacists perform blood glucose and cholesterol measurements, administer vaccinations, and perform drug reviews [11]. One of the many examples that confirms the legitimacy of screenings and highlights the critical role of a pharmacist is the blood pressure measurements in a pharmacy setting. The results from meta-analysis confirm that with the involvement of a pharmacist, blood pressure can be reduced by up to $7 \mathrm{mmHg}$, with the usual care of a family doctor [1]. Although the types of services provided by pharmacists in community pharmacies vary from country to country, more and more pharmacists are becoming involved in management of mediation therapy, for example in detection, exclusion, correction and prevention of drug problems. As part of pharmaceutical care, the pharmacist provides expert management of patient's medical records $[7$, 13].

Participants of this study expressed different opinion about the payment for screening for chronic diseases. The Saudis and the Poles were willing to pay around 10 - 26 PLN/SAR (2.5 - 6.6 USD), whereas the Americans, above 100 PLN/SAR (25.3 USD). The average cost for health screening services identified by a similar study conducted in Poland was 27.5 PLN [20]. In the publication from 2018 , patient opinion was reported regarding payment for screening tests. In that study, service for chronic kidney disease was included. As a result, $62.9 \%$ of respondents suggested readiness to pay at the average amount of 10-20 USD (39.5 - 79.0 PLN/SAR) [6]. Patients who participated in pharmacy health screening and who were at risk were more likely to pay for this service [3].

The introduction of additional health services provided by community pharmacies provides significant financial savings for both government and society. Expanding the scope of pharmacist-provided health services and counselling on medicines can reduce the number of people seeking professionals for help with any health problem. Research has consistently shown that preventive health screening contributes to significant reduction of costs in the healthcare system [4]. Cost effectiveness in health care is important. Moreover, it is critical to emphasize that the pharmacist's active participation in preventive health screenings helps with early detection of the disease, earlier initiation of treatment, improved recovery and better healthcare outcomes [18, 22]. Research showed that preventive screening for diabetes can help detect it about 3 years faster, compared to not having early detection of it $[12$, 22].

The source of funding for health screenings is a very important issue as it essential for successful implementation of the health screening services. Literature reports show that preventive screenings for diabetes, obesity, or hypertension are costeffective for patients and pharmacies [10, 23]. The vast majority of Saudis indicated preference for a community pharmacy as a source of financing the cost of screening, Poles chose the government, while the Americans prefer that both the government and the insurance company pay for health screenings. The remuneration model for community pharmacies should take into account the activities and services provided by the health care system, their value and total cost. It should save money for the health system, while achieving the desired health care outcomes. Most countries rely on one or more funding sources for health care. As pharmacists expand their services to patients, they may get revenues from a service or delivery fee (e.g., in France if the generic substitution target is met) or a capitalization fee (as for the minor ailments program in Scotland in the UK) [16]. Pharmaceutical care is successfully implemented in many European countries. It is generally financed from the health insurance budget (e.g., in the Netherlands, Germany and the United Kingdom) or from the margin that pharmacies earn by selling drugs (e.g., in Spain, Sweden and Finland). In the Netherlands, funding for the health care system is based on the social health insurance system. Dutch citizens are required to purchase health insurance covering a standard package of basic benefits. In contrast, healthcare in Great Britain is largely financed from public funds. These funds come from central taxes and, to a lesser extent, from social security contributions [8].

\section{Conclusions}

For many decades, other countries show that community pharmacies and highly qualified pharmacy 
FARMACIA, 2021, Vol. 69, 5

professionals provide many valuable patient-cantered services including early detection of health problems. The pharmacist-patient relationship involves assessment of health problems in context of other patientspecific conditions, health screenings, expert advice and if needed, referral to another health professional. Furthermore, pharmacists often work closely with a physician or other members of the medical team. This interprofessional patient-cantered collaboration results in visible measurable benefits for patients and the health care system. Implementation of a new health service to a community pharmacy should contribute to improvement of patient's health and quality of life. Patient opinions show a strong interest in community pharmacy-based health screenings. Expansion of the range of health services provided by a pharmacist can significantly improve patient outcomes, increase cost effectiveness in healthcare, and most of all, increase the prestige and usefulness of the pharmacist as a health professional engaged in patient-cantered care.

\section{Acknowledgement}

This research was funded by Poznan University of Medical Sciences [grant number 502-14-0331442909415].

\section{Conflict of interest}

The authors declare no conflict of interest.

\section{References}

1. Albasri A, Clark CE, Omboni S, McDonagh STJ, McManus RJ, Sheppard J, Effective detection and management of hypertension through community pharmacy in England. Pharm J., 2020; 304(7935): $1-33$.

2. Alzubaidi HT, Chandir S, Hasan S, McNamara K, Cox R, Krass I, Diabetes and cardiovascular disease risk screening model in community pharmacies in a developing primary healthcare system: a feasibility study. BMJ Open, 2019; 9(11): e031246: 1-11.

3. Breslow RM, Patient attitudes regarding pharmacistadministered memory screening in community pharmacies. J Am Pharm Assoc., 2013; 53(6): 648651.

4. Dalton K, Byrne S, Role of the pharmacist in reducing healthcare costs: current insights. Integr Pharm Res Pract., 2017; 6: 37-46.

5. Erku DA, Belachew SA, Mekuria AB, Haile KT, Gebresillassie BM, Tegegn HG, Ayele AA, The role of community pharmacists in patient counseling and health education: a survey of their knowledge and level of involvement in relation to type 2 diabetes mellitus. Integr Pharm Res Pract., 2017; 6:137-143.

6. Gheewala PA, Peterson GM, Zaidi STR, Jose MD, Castelino RL, Patient satisfaction with a chronic kidney disease risk assessment service in community pharmacies. Int J Clin Pharm., 2018; 40(2): 458463.
7. http://prawo.sejm.gov.pl/isap.nsf/download.xsp/W DU19910410179/U/D19910179Lj.pdf.

8. How to introduce pharmaceutical care in Poland. The role and challenges of a modern pharmacy. 2018. www2.deloitte.com/content/dam/Deloitte/pl/ Documents/ Reports/pl-raport-jak\%20wprowadzicw-Polsce-opieke-farmaceutyczna.pdf.

9. Melton BL, Lai Z, Review of community pharmacy services: what is being performed, and where are the opportunities for improvement?. Integr Pharm Res Pract., 2017; 6:79-89.

10. Newman TV, San-Juan-Rodriguez A, Parekh N, Swart EC, Klein-Fedyshin, M, Shrank WH, Hernandez I, Impact of community pharmacist-led interventions in chronic disease management on clinical, utilization, and economic outcomes: an umbrella review. Res Social Adm Pharm., 2020; 16(9): 1155-1165.

11. Pharmaceutical Group of European Union PGEU. Report, 2019. www.pgeu.eu/wp-content/uploads/ 2020/03/200402-PGEU-Annual-Report-2019.pdf.

12. Rahman M, Simmons RK, Hennings SH, Wareham NJ, Griffin SJ, How much does screening bring forward the diagnosis of type 2 diabetes and reduce complications? Twelve year follow-up of the Ely cohort. Diabetologia, 2012; 55: 1651-1659.

13. Rural Pharmacy and Prescription Drugs, 2015. www.ruralhealthinfo.org/topics/pharmacy-andprescription-drugs.

14. Skowron A, Bułaś L, Drozd M, Karolewicz B, Machalska J, Prospects for the development of pharmacy in Poland until 2030. Farm Pol., 2013; 69: 485-495.

15. Staudt AM, Amtower JE, George J, Daniels NC, Allou, JN, Laswell EM, Ballentine J, The Correlation of Free Health Screenings at Community Pharmacies on Diabetes. Innov Pharm., 2017; 8(2): 1-4.

16. The legal and regulatory framework for community pharmacies in the WHO European Region. WHO, 2019. www.pgeu.eu/wp-content/uploads/2019/10/ WHO-Europe-Report-Regulatory-framework-forcommunity-pharmacies-October-2019.pdf.

17. Waszyk-Nowaczyk M, Guzenda W, Plewka B, Michalak M, Cerbin-Koczorowska M, Stryczyński $Ł$, Byliniak M, Ratka A, Opinions of patients on community pharmacy-based blood pressure control counselling model. Farmacia, 2020; 68(4): 612219.

18. Waszyk-Nowaczyk M, Guzenda W, Plewka B, Michalak M, Cerbin-Koczorowska M, Stryczyński $Ł$, Byliniak M, Ratka A, Screening Services in a Community Pharmacy in Poznan (Poland) to Increase Early Detection of Hypertension. J Clin Med., 2020; 9(8): 2572: 1-11.

19. Waszyk-Nowaczyk M, Simon M, Szukalska B, Pharmaceutical care as an area for cooperation between physician and pharmacist. Now Lek., 2013; 82(3): 262-265.

20. Waszyk-Nowaczyk M, Skura, O, Michalak M, Ratka A, Opinions of pharmacists on community pharmacy-based health screenings for common chronic diseases. Acta Pol Pharm, 2018; 75: 819-826.

21. World Health Organization 2016: Global report on diabetes. 
FARMACIA, 2021, Vol. 69, 5

http://apps.who.int/iris/bitstream/10665/204871/1/9 789241565257_eng.pdf.

22. Wright D, Little R, Turner D, Thornley T, Diabetes Screening Through Community Pharmacies in England: A Cost-Effectiveness Study. Pharmacy, 2019; 7(1): 30: $1-12$.
23. Yuan C, Ding Y, Zhou K, Huang Y, Xi X, Clinical Outcomes of Community Pharmacy Services: A Systematic Review and Meta-Analysis. Health Soc Care Community, 2019; 27(5): 567-587. 